\title{
Defining Endocytic Pathways of Fucoidan-Coated PIBCA Nanoparticles from the Design of their Surface Architecture
}

\author{
M. C. B. Lira-Nogueira ${ }^{1,2,3} \cdot$ V. P. Gibson ${ }^{2} \cdot$ V. Nicolas ${ }^{4} \cdot$ N. S. Santos-Magalhães ${ }^{2} \cdot$ C. Vauthier $^{3}$ (1)
}

Received: 21 October 2021 / Accepted: 13 February 2022 / Published online: 1 March 2022

(c) The Author(s), under exclusive licence to Springer Science+Business Media, LLC, part of Springer Nature 2022

\begin{abstract}
Purpose This work investigated the endocytic pathways taken by poly(isobutylcyanoacrylate) (PIBCA) nanoparticles differing in their surface composition and architecture, assuming that this might determine their efficiency of intracellular drug delivery.

Methods Nanoparticles (A0, A25, A100, R0, R25) were prepared by anionic or redox radical emulsion polymerization using mixtures of dextran and fucoidan (0,25, $100 \%$ in fucoidan). Cell uptake was evaluated by incubating J774A.1 macrophages with nanoparticles. Endocytic pathways were studied by incubating cells with endocytic pathway inhibitors (chlorpromazine, genistein, cytochalasin D, methyl-ß-cyclodextrin and nocodazole) and nanoparticle uptake was evaluated by flow cytometry and confocal microscopy.

Results The fucoidan-coated PIBCA nanoparticles $\mathrm{A}_{25}$ were internalized 3-fold more efficiently than $\mathrm{R}_{25}$ due to the different architecture of the fucoidan chains presented on the surface. Different fucoidan density and architecture led to different internalization pathway preferred by the cells. Large $\mathrm{A}_{100}$ nanoparticles with surface was covered with fucoidan chains in a loop and train configuration were internalized the most efficiently, 47-fold compared with $\mathrm{A}_{0}$, and 3-fold compared with $\mathrm{R}_{0}$ and $\mathrm{R}_{25}$ through non-endocytic energy-independent pathways and reached the cell cytoplasm.

Conclusion Internalization pathways of PIBCA nanoparticles by J774A.1 macrophages could be determined by nanoparticle fucoidan surface composition and architecture. In turn, this influenced the extent of internalization and localization of accumulated nanoparticles within cells. The results are of interest for rationalizing the design of nanoparticles for potential cytoplamic drug delivery by controlling the nature of the nanoparticle surface.
\end{abstract}

KEY WORDS cellular uptake $\cdot$ endocytic pathway $\cdot$ fucoidan $\cdot$ nanoparticles $\cdot$ PIBCA

\section{LIST OF ABBREVIATIONS}

AEP Anionic emulsion polymerization

AMP Actin mediated pathway

CCIP Clathrin-caveolae independant pathways,

C. Vauthier

christine.vauthier@universite-paris-saclay.fr

1 Centro Acadêmico de Vitória, Universidade Federal de Pernambuco, Vitória de Santo Antão, Brazil

2 Laboratório de Immunopatologia Keizo-Asami, Universidade Federal de Pernambuco Recife, Recife, Brazil

3 CNRS, Institut Galien Paris-Saclay, Université Paris-Saclay, 92296, Châtenay, Malabry, France

4 Plateforme d'Imagerie Cellulaire MIPSIT, UMS-IPSIT, Inserm, CNRS, Ingénierie et Plateformes au Service de l'Innovation Thérapeutique, Université Paris-Saclay, CNRS, UMR 8612, Université Paris-Sud, 5 Rue J.B. Clément, 92296 Châtenay, Malabry Cedex, France

\begin{tabular}{|c|c|}
\hline CLRs & C-type lectin receptors \\
\hline $\mathrm{Cm}$ & $\begin{array}{l}\text { Nanoparticle concentration in the dispersion } \\
\text { expressed in g. } \mathrm{mL}^{-1} \text {. }\end{array}$ \\
\hline CME & Clathrin mediated endocytosis, \\
\hline CvME & Caveolae mediated endocytosis, \\
\hline$D_{H}$ & Hydrodynamic diameter \\
\hline FACS & Fluorescence activated cell sorting \\
\hline FBS & Fetal bovine serum \\
\hline IBCA & Isobutylcyanoacrylate \\
\hline LRMP & Lipid raft mediated pathways, \\
\hline MeßCD & Methyl-ß-cyclodextrin \\
\hline MR & Mannose receptor \\
\hline MTP & Microtubule mediated pathways, \\
\hline MWCO & Molecular weight cutoff \\
\hline$N$ & $\begin{array}{l}\text { Nanoparticle concentration expressed in number } \\
\text { of nanoparticles per } \mathrm{mL}\end{array}$ \\
\hline NLRs & $\begin{array}{l}\text { Nucleotide-binding domain leucine-rich repeat- } \\
\text { containing receptors }\end{array}$ \\
\hline
\end{tabular}




$\begin{array}{ll}\text { NP } & \text { Nanoparticles } \\ \text { PDI } & \text { Polydispersity index } \\ \text { PIBCA } & \text { Poly(isobutylcyanoacrylate) } \\ \text { PRRs } & \text { Pattern recognition receptors } \\ \text { RREP } & \text { Redox radical emulsion polymerization } \\ \text { SR-A } & \text { Scavenger receptor type A } \\ \text { SRs } & \text { Scavenger receptors } \\ \text { TLRs } & \text { Toll-like receptors } \\ \rho & \text { volumetric mass of the nanoparticles }\end{array}$

\section{INTRODUCTION}

New-generation drugs, including peptides, proteins and nucleic acids such as DNA and RNA, need sophisticated delivery systems that can transport them to a specific intracellular compartment to exert their desirable therapeutic effect (1-5). A recent example is that of the mRNA vaccines developed in the context of the COVID-19 pandemic which require cytoplasmic delivery of the mRNA in order for it to be effective (4). The use of nanosystems was essential for the success of these vaccines, demonstrating the formidable capacity of these carriers to achieve cytoplasmic delivery of active ingredients, including in clinical settings. As well as the lipid nanoparticles used in the design of the COVID-19 mRNA vaccines, nanoparticles prepared from polymers can also be used to deliver drugs to the cell cytoplasm. For example, nanoparticles composed of poly(isobutylcyanoacrylate) (PIBCA) have long been recognised as being able to allow cytoplasmic delivery of drugs, including anticancer molecules and nucleic acids, thereby opening the way to a wide range of therapeutic perspectives (6-13).

However, better control of the delivery of new drug candidates within cells that allows them to reach a well-defined intracellular compartment would be a great advantage for their activity. This could be achieved by controlling the intracellular trafficking of the nanoparticulate drug carrier by directing the carrier to a particular endocytic pathway for entering the cell (14). At present, incomplete understanding of the influence of the nanoparticle properties on their interactions with cells is a bottleneck to improving the design of carriers so that they can deliver their cargo to the desired intracellular compartment. Although this is a challenging subject, a better understanding on how the endocytic pathways of a nanomaterial can be manipulated by its properties would certainly open up tremendous perspectives towards achieving more efficient and precise intracellular delivery of drugs $(3,5,14,15)$.

According to the literature, the intracellular destination of nanocarriers is affected by their physicochemical properties $(1,5,16,17)$. The nanoparticle properties that alter internalization pathway are their surface chemistry, their chemical composition, their size, their surface charge expressed as the zeta potential, and their shape, but the endocytic pathway taken by the nanoparticles also depends on the cell type (5, $14,18,19)$. As far as the nanoparticle surface design is concerned, the influence of the topography and the molecular architecture of the nanoparticle surface on interactions with biological systems remains poorly documented. However, clear effects have been observed in studies evaluating the in-vivo biodistribution (20), the activation of the complement system by nanoparticles (21-23) and the entry of nanomedicines into cells (2). An improvement of our knowledge about the influence of the nanomaterial surface properties at a molecular level on the cell entry pathway has become central to optimizing intracellular delivery of drugs $(1,19,24-26)$.

In a previous work, we described differences in cytoplasmic accumulation within J774A.1 macrophage-like cells of a series of nanoparticles made of PIBCA differing by their surface content in fucoidan, a sulfated polysaccharide (27), and also by the molecular architecture of the polysaccharide chains on the nanoparticle surface (28). Fucoidan was chosen because this polysaccharide is recognized by macrophage scavenger receptors (MSR). Based on the results, it was postulated that entry into cells of these fucoidan-coated nanoparticles might be increased compared with uncoated nanoparticles and occurred through different internalization pathways according to the nature of the nanoparticle surface. The present work was aimed at deciphering the internalization pathways taken by these nanoparticles in J774A.1 macrophages, a cell line commonly used to study various aspects of nanoparticle uptake (29). It was designed to improve our understanding on the intracellular entry mechanisms and how this could be controlled by the surface design of the nanoparticles. Experiments were carried out in the presence of proteins contained in the fetal bovine serum (FBS) routinely added to the cell culture medium. It investigated the energy dependency of the intracellular uptake mechanisms, the uptake after a short contact time of the nanoparticles with the cells and the endocytosis of the nanoparticles in presence of inhibitors of different endocytic pathways. The internalization of fucoidan-coated nanoparticles by the cells was monitored using confocal microscopy and fluorescence activated cell sorting (FACS) as described previously $(14,19)$.

\section{MATERIALS AND METHODS}

\section{Materials}

Isobutylcyanoacrylate (IBCA) was a gift from Henkel Biomedical (Dublin, Ireland). Dextran (Mw 66900) was purchased from Sigma (Saint Quentin Fallavier, France). Cerium (IV) from cerium (IV) ammonium nitrate was purchased from Fluka (Saint Quentin Fallavier, France). Polyfluor ${ }^{\circledR} 570$ (methacryloxyethyl thiocarbamoyl 
rhodamine B) was supplied from Polyscience (Biovalley, Marne la Vallee, France). Fucoidan was extracted and purified from Fucus vesiculosus according to the method described by Lira et al., 2011 (28). Endocytic pathway inhibitors (cytochalasin D, genistein, chlorpromazine and nocodazol) were purchased from Sigma Aldrich, and methyl- $\beta$ cyclodextrin (MeßCD) was provided by Wacker Chemical.

\section{Methods}

\section{Preparation of the PIBCA Nanoparticles}

Nanoparticles bearing a coating layer of dextran and/or fucoidan were prepared by anionic or redox radical emulsion polymerization (28). To synthesize the nanoparticles by anionic emulsion polymerization (AEP), the polysaccharides in various proportions (dextran $100 \%$, fucoidan/dextran 25/75, fucoidan $100 \%$ ) (50 mg) were dissolved in $10 \mathrm{~mL}$ Milli-Q ${ }^{\circledR}$ water the $\mathrm{pH}$ of which was adjusted to 2.5 with $0.1 \mathrm{M} \mathrm{HCl}$. The solution was placed under magnetic stirring $(1000 \mathrm{rpm}$, at room temperature) and subsequently, $100 \mu \mathrm{L}$ of monomer IBCA were added. A solution of Polyfluor ${ }^{\circledR} 570(100 \mu \mathrm{L}, 5$ $\mathrm{mg} \cdot \mathrm{mL}^{-1}$ in acetonitrile:water, $1: 1$ ) was added $5 \mathrm{~min}$ after the addition of IBCA. The system was left to polymerize for a total of 3 hours to obtain a dispersion of PIBCA nanoparticles. To prepare nanoparticles by redox radical emulsion polymerization (RREP), the polysaccharides in various proportions (dextran 100\%, fucoidan/dextran 25/75) (135.6 mg) were dissolved in $9.3 \mathrm{~mL}$ of nitric acid and maintained at $40{ }^{\circ} \mathrm{C}$ under stirring with nitrogen bubbling for 10 minutes. Then, under strong magnetic stirring $(1500 \mathrm{rpm}), 0.7 \mathrm{~mL}$ of cerium (IV) ammonium nitrate $(0.08 \mathrm{M}$ in $0.2 \mathrm{M}$ nitric acid) and immediately after $0.5 \mathrm{~mL}$ of monomer IBCA were added. One $\mathrm{mL}$ of a solution of Polyfluor ${ }^{\circledR} 570\left(2 \mathrm{mg} \cdot \mathrm{mL}^{-1}\right.$, acetonitrile:water, 1:1) was added 2 minutes after the addition of IBCA. The system was left to polymerize at $40{ }^{\circ} \mathrm{C}$ for 1 hour. The PIBCA nanoparticle dispersion obtained was cooled to room temperature using an ice bath.

Nanoparticles were designated $A_{x}$ and $R_{x}$ depending on the preparation method, AEP and RREP respectively, where $\mathrm{x}$ was the percentage of fucoidan introduced into the formulation.

\section{Purification of the Nanoparticles}

Nanoparticles were purified by dialysis using a membrane with a molecular weight cut off (MWCO) of 100,000 g.mol ${ }^{-1}$ (Spectrapor ${ }^{\circledR}$ membrane, width: $16 \mathrm{~mm}$; diameter: $10 \mathrm{~mm}$; Biovalley, Marne la Vallee, France). The dialysis was performed against distilled water to eliminate all unused reagents and also to neutralize the formulation. The distilled water $(1 \mathrm{~L})$ was changed twice after 30 minutes and once before overnight dialysis. Purified nanoparticles were stored at $4{ }^{\circ} \mathrm{C}$ until use.

\section{PIBCA Nanoparticle Characterization}

All nanoparticles were characterized by evaluating their size, expressed as the mean hydrodynamic diameter $\left(D_{H}\right)$, their polydispersity index (PDI), their zeta potential $(\zeta)$ and the nanoparticle concentration $\left(C_{\mathrm{m}}\right)$. The diameter and zeta potential were determined using a Zetasizer (Malvern Instrument, UK), after diluting the nanoparticles in water and $\mathrm{KCl}$ $(1 \mathrm{mM})$, respectively. Nanoparticle concentration was determined by evaluating the weight of the dried residue obtained after lyophilization of a sample of $200 \mu \mathrm{L}$ of nanoparticle dispersion. To perform the lyophilization, the sample was frozen at $-20^{\circ} \mathrm{C}$ and the lyophilization was carried out under vaccuum $\left(10^{-4} \mathrm{Bar}\right)$ for 24 hours using an Alpha 1-2 LD plus freeze dryer apparatus (Bioblock Scientific). The concentration in nanoparticles, $C_{m}$, obtained from this determination was given in mg.mL $\mathrm{mL}^{-1}$. Equation 1 was used to convert $C_{m}$ in a concentration in number of nanoparticles per mL, $N$.

$N=\frac{6 \times C_{m}}{\pi \times \rho \times D_{H}^{3}}$

In which, $D_{H}$ was the mean hydrodynamic diameter of the nanoparticles determined by DLS and $\rho$ the volumetric mass of the nanoparticles $\left(\rho=1.14 \mathrm{~g} . \mathrm{cm}^{-3}(30)\right)$.

\section{Cell Culture Experiments}

The macrophage-like J774A.1 cell line (ATCC ${ }^{\circledR}$ TIB67TM) supplied by ATCC (Manassas, USA) was used in this work. Cells were grown in a $5 \% \mathrm{CO}_{2}$ atmosphere at $37{ }^{\circ} \mathrm{C}$ in complete RPMI medium (RPMI medium (Gibco, Cergy-Pontoise, France) supplemented with 10\% FBS (Gibco, CergyPontoise, France), Penicillin $50 \mathrm{IU} / \mathrm{mL}$, Streptomycin 50 $\mathrm{UI} / \mathrm{mL}$ ). Experiments were performed between the eighth and the fourteenth passages. Viable cells were counted in a hemocytometer (Glasstic ${ }^{\circledR}$ slide) to adjust the cell concentration to $1 \times 10^{5}$ viable cells/well for use in further experiments. To evaluate the uptake of PIBCA nanoparticles by the J774A.1 macrophages, the nanoparticles were added at a concentration of $3 \times 10^{10} \mathrm{NP} /$ well in wells containing $1 \times$ $10^{5}$ cells. The nanoparticle concentration used in this work was considered as non cytotoxic as being below the $\mathrm{IC}_{50}$ (approximately $10 \mu \mathrm{g} . \mathrm{mL}^{-1}$ ) reported by Lira et al. (28). Incubation conditions depended on the type of evaluation and are explained in the following sections.

Energetic Dependency of Nanoparticle Uptake and Influence of the Duration of the Incubation The cells were seeded in a TPP 6-well plate $\left(1 \times 10^{5}\right.$ cells/well $)$ and incubated at 37 
${ }^{\circ} \mathrm{C}$ and $5 \% \mathrm{CO}_{2}$ for 24 hours in complete RPMI medium (as described above). Then, the culture medium was changed and the plates was placed at $37{ }^{\circ} \mathrm{C}$. Pre-equilibrated nanoparticles $\left(1 \times 10^{3} \mathrm{NP} \cdot \mathrm{mL}^{-1}\right)$ at $37{ }^{\circ} \mathrm{C}$ were then added to each well and maintained at the predefined temperature for 1 hour. Similar experiments were carried out in parallel by incubating the cells with the nanoparticles at $+4{ }^{\circ} \mathrm{C}$ to evaluate the influence of the energy-dependent mechanisms on the uptake of nanoparticles. The uptake of nanoparticles after a short-term incubation was evaluated after 10 minutes of incubation with the cells at $37^{\circ} \mathrm{C}$, using flow cytometry and confocal microscopy. All assays were performed and analyzed in duplicate.

Investigation of Endocytic Pathways of PIBCA Nanoparticles Using Endocytic Pathway Inhibitors Five pharmacological inhibitors of endocytic pathways and their concentrations to be used in our experiments were chosen from a litterature review (Table S1 - Supplementary material). They were used at the following concentrations in the present experiments: chlorpromazine, an inhibitor of the clathrin-dependent pathway $(28 \mu \mathrm{M})$, genistein, an inhibitor of the caveolae-dependent pathway $(200 \mu \mathrm{M})$, cytochalasin $\mathrm{D}$, an inhibitor of the macropinocytosis and actin-mediated endocytosis pathways $(40 \mu \mathrm{M}), \mathrm{Me} \beta \mathrm{CD}$ known for depleting lipid rafts $(3000 \mu \mathrm{M})$ and nocodazole, an inhibitor of the microtubule-mediated pathway $(10 \mu \mathrm{M})$. For these experiments, the cells were seeded in a TPP 6-well plate $\left(1 \times 10^{5}\right.$ cells/well $)$ and incubated at $37{ }^{\circ} \mathrm{C}$ and $5 \% \mathrm{CO}_{2}$ for 24 hours in complete RPMI medium. Then, $250 \mu \mathrm{L}$ of one of the endocytic pathway inhibitor solutions was added to the wells and the cells were incubated for a further $30 \mathrm{~min}$ at $37^{\circ} \mathrm{C}$. Thereafter, nanoparticles at a final concentration of $3 \times 10^{10} \mathrm{NP} . \mathrm{mL}^{-1}$ in culture medium were added and the cells were incubated for another 1 hour at $37{ }^{\circ} \mathrm{C}$. After incubation, the uptake of the nanoparticles by the cells was evaluated by flow cytometry and confocal microscopy. Results were expressed as relative fluorescence comparing the fluorescence due to the nanoparticles taken up by the cells incubated in the presence of endocytic pathway inhibitors with that of cells incubated in the same conditions but without the endocytic pathway inhibitor. All experiments were performed in duplicate.

\section{Evaluation of the Uptake of Nanoparticles by the Cells}

Flow Cytometry After incubation with the nanoparticles under the different conditions, the cells were washed three times with culture medium and detached using a scrapper. The cell suspension obtained was transferred to Eppendorf ${ }^{(}$ type microtubes $(300 \mu \mathrm{L})$ and analyzed by flow cytometry (MoFlo XDP (Beckman Coulter) driven by the Summit software). Each analysis considered 10,000 cells measured in each sampling gate.

Live Cell Confocal Microscopy For live cell confocal microscopy, J774A. 1 macrophages $\left(1 \times 10^{5}\right.$ cells/well) were grown on a $25 \mathrm{~mm}$ glass coverslip placed in a 6-well plate for 48 hours at $37{ }^{\circ} \mathrm{C}$ and $5 \% \mathrm{CO}_{2}$. All incubation condition were as those explained above.

To test cell viability, calcein AM (Life Technologies) was used. Calcein AM is a non fluorescent compound but when it penetrates into living cells, it is hydrolysed by intracellular esterases producing a strongly fluorescent calcein species in the cytoplasm of the cells. To highlight living cells during the confocal microscopy observations, $200 \mu \mathrm{L}$ of calcein AM $(3 \mu \mathrm{M})$ (Life Technologies) were added directly to cells and incubated for 5 minutes at room temperature, protected from light. Then, the glass coverslip was transferred into an Attofluor ${ }^{\circledR}$ cell chamber for visualization. A sample of $100 \mu \mathrm{L}$ of each type of nanoparticles and $1 \mathrm{~mL}$ of fresh culture medium were added, achieving a final concentration of $3 \times 10^{10} \mathrm{NP} \cdot \mathrm{mL}^{-1}$. The cells were observed for 1 hour. The assay was performed twice for each nanoparticle, and the image analysis was performed with Image J (version 1.49o) software (NIH, USA) at 10 different positions on each sample (up to 100 cells/sample). The images were acquired using an inverted confocal laser-scanning microscope LSM 510Meta (Carl Zeiss, Germany) using a Plan-Apochromat $63 \mathrm{X} / 1.4$ objective lens, equipped with an $\arg$ on $(488 \mathrm{~nm}$ excitation wavelength) and a helium-neon laser (543 nm excitation wavelength).

The green and the red fluorescence emissions were collected with a $505-550 \mathrm{~nm}$ band-pass and a $560 \mathrm{~nm}$ longpass emission filter respectively, under a sequential mode. DIC (Differential Interferential Contrast) images were obtained simultaneously with the green channel. The pinhole was set at 1.0 Airy unit. 12-bit numerical images were acquired with LSM 510 software version 3.2. For each condition, a 1-hour time lapse was applied and for each time point, a z-stack of images was collected every $4 \mu \mathrm{m}$ along the $\mathrm{z}$-axis from the up level ( $1^{\text {st }} \mathrm{z}$-stack) to bottom $\left(40^{\text {th }}\right.$ $\mathrm{z}$-stack). The $19^{\text {th }} \mathrm{z}$-stack corresponds to the z-stack in the middle of the cells. All observations were made with same settings of the camera to allow fluorescence analysis in comparable conditions.

\section{Statistical Analysis}

Data were plotted in Prism Software (GraphPad Software 7, La Jolla, CA, USA) and statistical significance was calculated by Student t-test and expressed as: ** $(p<0.05)$, or $* * * *$ ( $p$ $<0.0001)$. 


\section{RESULTS AND DISCUSSION}

In a previous work, we reported differences in the intracellular accumulation of a series of PIBCA nanoparticles in the well-known J774A.1 macrophage cell line (28). These PIBCA nanoparticles differed by the ratio between fucoidan and dextran at their surface and by the molecular architecture of the polysaccharides grafted on the surface depending on the method of polymerization used to prepare the nanoparticles (31-33). Differences in the intracellular distribution of these nanoparticles in the J774A.1 macrophage cell line have been reported, suggesting that they might enter cells by different endocytic pathways. Unraveling the mechanisms involved in the internalization of nanoparticles by cells would be of great value in designing drug carriers that could enter cells by a specific pathway and improve drug delivery to the desired intracellular compartment, such as the

Table I Physicochemical Characteristics of PIBCA Nanoparticles Obtained by Anionic Emulsion Polymerization (A) and Redox Radical Emulsion Polymerization (R) Using Different Percentage of Fucoidan $\left(0,25\right.$ and 100\%) in a Blend of Dextran and Fucoidan. $\mathrm{D}_{\mathrm{H}}$ $=$ Hydrodynamic diameter; $\mathrm{V}=$ Volume; $\mathrm{PDI}=$ Polydispersity index; $\zeta=$ Zeta potential; $\mathrm{C}_{\mathrm{m}}=$ Nanoparticle concentration

\begin{tabular}{llllll}
\hline \multicolumn{5}{c}{ Physicochemical parameters } \\
\cline { 3 - 6 } $\begin{array}{l}\text { Nano- } \\
\text { particle } \\
\text { Type }\end{array}$ & $\begin{array}{l}\mathrm{D}_{\mathrm{H}} \\
(\mathrm{nm})\end{array}$ & $\begin{array}{l}{\mathrm{Vx} 10^{6}} \\
\left(\mathrm{~nm}^{3}\right)\end{array}$ & $\mathrm{PDI} \pm \mathrm{SD}$ & $\begin{array}{l}\zeta \\
(\mathrm{mV})\end{array}$ & $\begin{array}{l}\mathrm{C}_{\mathrm{m}} \\
\left(\mathrm{mg} . \mathrm{mL}^{-1}\right)\end{array}$ \\
\hline $\mathrm{A}_{0}$ & $254 \pm 5$ & 8.58 & $0.26 \pm$ & $-5.5 \pm 0.3$ & $11 \pm 1$ \\
& & & 0.05 & & \\
$\mathrm{~A}_{25}$ & $351 \pm 5$ & 22.6 & $0.10 \pm$ & $-33.2 \pm$ & $9.5 \pm 1$ \\
& & & 0.02 & 0.4 & \\
$\mathrm{~A}_{100}$ & $495 \pm 18$ & 63.5 & $0.11 \pm$ & $-55.0 \pm$ & $10 \pm 0.5$ \\
& & & 0.09 & 1.0 & \\
$\mathrm{R}_{0}$ & $284 \pm 3$ & 12.0 & $0.09 \pm$ & $-5.2 \pm 0.4$ & $32.5 \pm 1$ \\
& & & 0.02 & & \\
$\mathrm{R}_{25}$ & $361 \pm 2$ & 24.6 & $0.16 \pm$ & $-14.0 \pm$ & $28 \pm 0.0$ \\
& & & 0.02 & 0.3 & \\
$\mathrm{R}_{100}$ & Aggre- & $\mathrm{ND}^{*}$ & $\mathrm{ND} *$ & $\mathrm{ND}^{*}$ & $\mathrm{ND}$ \\
& gates & & & & \\
\hline
\end{tabular}

*ND - non-determined cell cytoplasm. Thus, the present work was aimed to study nanoparticle internalization and decipher the mechanisms by which each type of nanoparticles in this series were endocytosed in the J774A.1 macrophage cell line.

\section{Properties of the PIBCA Nanoparticles}

As shown in Table I, the properties of the nanoparticles synthesized for this work were consistent with those described in our previous work (28) as a result of the high reproducibility generally observed with the methods of nanoparticle synthesis employed. The hydrodynamic diameter (nm) of the nanoparticles increased when the amount of fucoidan used in the polysaccharide mixture increased. In contrast, the zeta potential decreased with increasing fucoidan content. This could be explained by the negative charges carried by the fucoidan chains. This increase of the absolute value of the zeta potential reflects an increase of the charge density around the nanoparticles and this could explain the increase in size of the nanoparticles due to an increase in the repulsion between polysaccharide chains grafted on the nanoparticle surface. This effect could contribute to an expansion of the polysaccharide corona surrounding the nanoparticle core and hence the nanoparticle size, as suggested in a previous work considering PIBCA nanoparticle prepared with other charged polysaccharides (32). As shown previously, the nanoparticles presented a spherical shape with core-corona structure (28). The nanoparticle surface design is illustrated on the Fig. 1 based on previous results $(31,33)$.

With exception of $\mathrm{R}_{100}$, which formed aggregates and was therefore discarded, all the other preparations produced dispersions of nanoparticles with hydrodynamic diameters above $200 \mathrm{~nm}$. According to the literature $(5,14,19)$, nanoparticles in this size range would be taken up by cells by macropinocytosis or phagocytosis pathways. However, as well as size, other physicochemical properties of nanoparticles, such as shape, surface composition and charge density, can influence their cell internalization $(34,35)$, emphasizing the importance of analyzing the whole picture. Several cell membrane proteins like clathrin and dynamin can play a crucial role in the endocytic pathways but, due to the nanoparticle size, pathways involving caveolae would not be expected
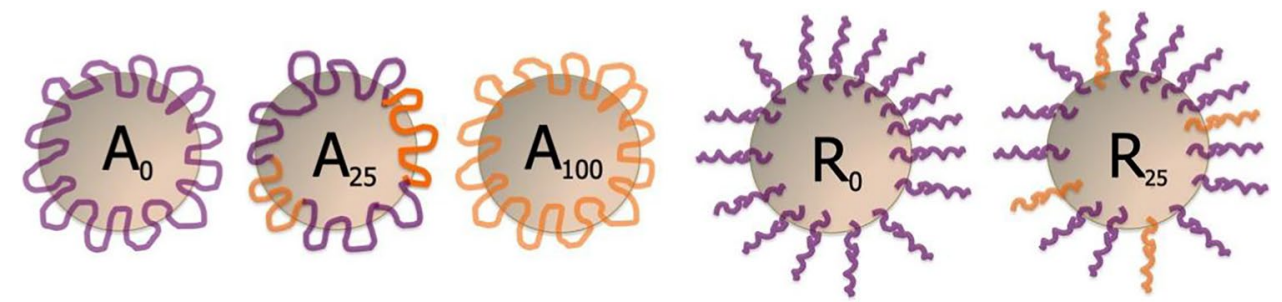

Fig. 1 Schematic structures of nanoparticles obtained in this work by anionic emulsion polymerization with different amount of fucoidan 0,25 and $100 \%\left(\mathrm{~A}_{0}, \mathrm{~A}_{25}\right.$ and $\mathrm{A}_{100}$, respectively) in the dextran-fucoidan mixture and by redox radical emulsion polymerization with 0 and $25 \%$ of fucoidan in the dextran-fucoidan mixture $\left(\mathrm{R}_{0}\right.$ and $\mathrm{R}_{25}$ respectively). Orange lines indicate fucoidan and purple lines indicate dextran. 
to be involved based on the current understanding of this mechanism. The zeta potential of the fucoidan-bearing nanoparticles was negative, varying in magnitude depending on the fucoidan composition at the nanoparticle surface. It is noteworthy that the zeta potential of the nanoparticles $\mathrm{A}_{25}$ and $R_{25}$ was quite different although these nanoparticles had the same fucoidan content in the corona (25\%). A more negative value was observed with $\mathrm{A}_{25}$, about 2-fold lower $\left(\zeta\left(\mathrm{A}_{25}\right)=-33.2 \pm 0.4 \mathrm{mV}, \zeta\left(\mathrm{R}_{25}\right)=-14.0 \pm 0.3 \mathrm{mV}\right)$, in which the fucoidan chains were expected to adopt a loop and train configuration which would expose a high proportion of the negative charges of the fucoidan chains to the dispersing media (Fig. 1). In contrast, on the surface of the nanoparticle $\mathrm{R}_{25}$, the fucoidan and dextran chains grafted by one end to the nanoparticle core would form a dense brush in which the negative charges of the fucoidan might be hidden, resulting in a lower absolute value of zeta potential. The configuration in loops or brush of polysaccharide chains grafted on PIBCA nanoparticle surfaces prepared by the AEP and RREP methods respectively was demonstrated in previous studies considering dextran-coated and chitosancoated nanoparticles $(31,33)$.

\section{Evaluation of the Uptake of the Different PIBCA Nanoparticles By The J774A.1 Macrophage Cell Line}

Preliminary experiments performed to evaluate the uptake of the nanoparticles by the J774A.1 macrophage cell line used the same incubation conditions as in previous work $\left(37^{\circ} \mathrm{C}\right.$, 1 hour) (28). Differences in the uptake of the nanoparticles by the cells were observed when comparing nanoparticles with different content of fucoidan within the series $A$ and $R$ as well as nanoparticles from series $\mathrm{A}$ and $\mathrm{R}$ with the same fucoidan content (Fig. 2B). Living cell confocal microscopy showed that all types of PIBCA nanoparticles considered in this work were internalized by J774A.1 macrophages.

The fluorescence was spread throughout the cell thickness, indicating that nanoparticles were able to penetrate cells and be distributed within them (Fig. 2B and Fig. 3). Image analysis of the confocal micrographs highlighted marked differences in the uptake of nanoparticles by the cells depending on their content in fucoidan, as seen in Fig. 2A, B (10 and 60 minutes of incubation, respectively) and their type A or R at identical fucoidan content (Fig. 4). The results from these sets of experiments were consistent with those of our previous work. They also supported the hypothesis that the uptake of the nanoparticles by the cells occurred through different pathways depending on the composition and molecular architecture of their surface. While conclusions from the two works were consistent, we could not compare the data on a quantitative basis due to slight changes introduced into the experimental protocols in the present study. Indeed, in our previous work, the uptake of nanoparticles by cells was evaluated from confocal microscopy images of cells fixed with paraformaldehyde while this was carried out on living cells in the present study. Another difference between the two studies was the expression of the concentration in nanoparticles to which cells were exposed.

Figure 4 shows the cellular uptake of the different nanoparticles. In Fig. 4A confocal images show the nanoparticle internalization in a qualitative way and the differences in fluorescence intensity are clearly illustrated in the $3 \mathrm{D}$ graph (Fig. 4B). The differences were confirmed after quantification measuring the fluorescence of at least 100 cells from 10 different places in each sample (Fig. 4C).
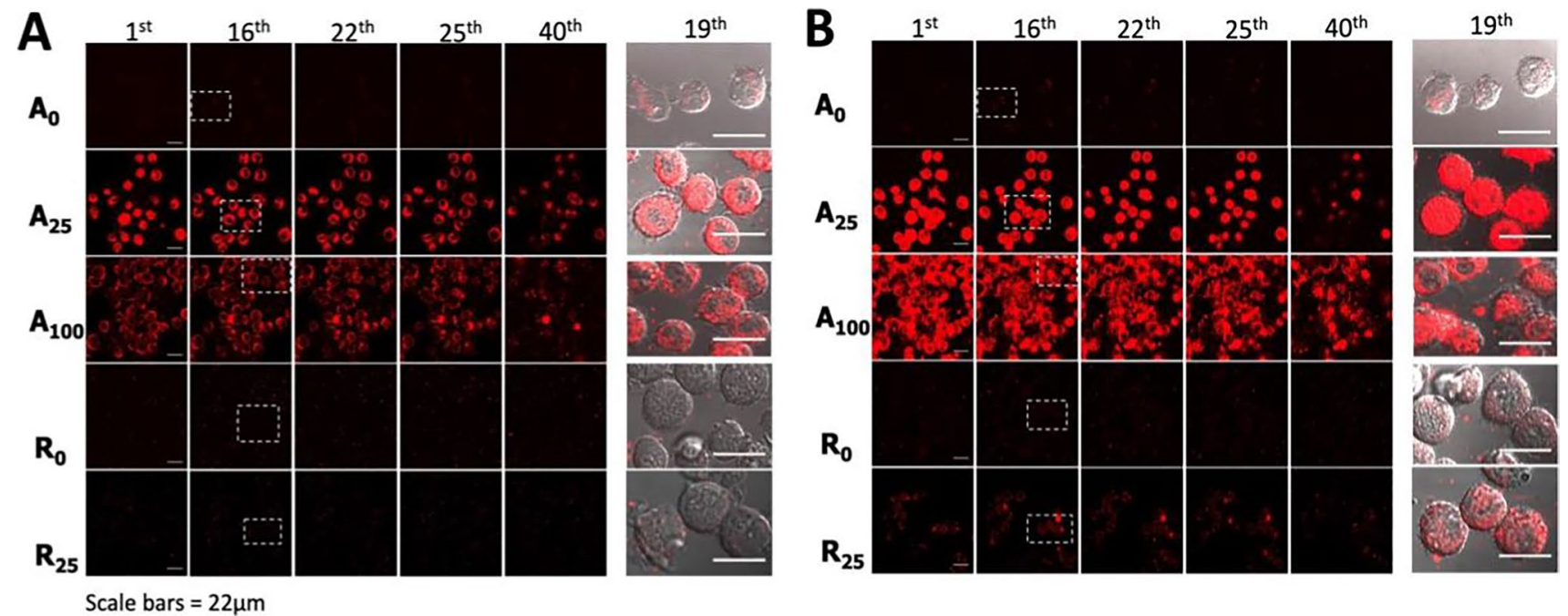

Fig. 2 Fluorescence at different thickness of cells, from 1 to $40 \mathrm{z}$-stack with $40 \mu \mathrm{m}$ each, incubated with different nanoparticles for 10 (A) and 60 (B) minutes. The enlarged zone shown on the $19^{\text {th }} \mathrm{z}$-stack, which corresponds to the middle of the cells, was just above that marked on the 16th z-stack with the white rectangle. Scale bars correspond to $22 \mu \mathrm{m}$. 
Fig. 3 Fluorescence images of $\mathrm{A}_{0}$ (A), $\mathrm{A}_{25}$ (B), $\mathrm{A}_{100}(\mathrm{C}), \mathrm{R}_{0}$ (D) and $\mathrm{R}_{25}$ (E) nanoparticles. The images shown z-stack that corresponds to the middle of the cells after 1 hour incubation. Insert shows fluorescence of calcein. Scale bars correspond to $22 \mu \mathrm{m}$.
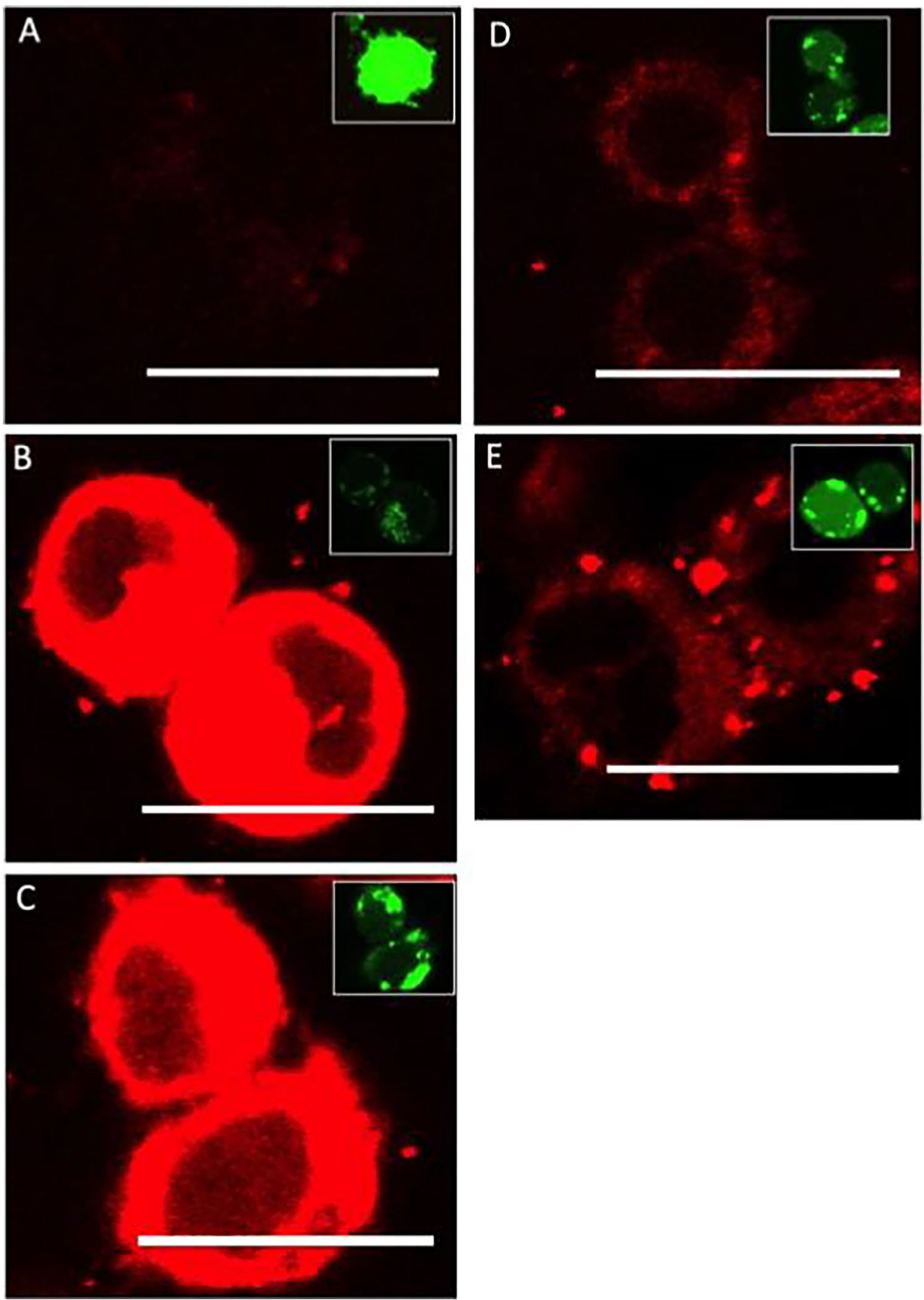

Marked differences in the fluorescence of the J774A.1 macrophages was revealed depending on the type of nanoparticles with which they were incubated. When incubated with nanoparticles without fucoidan prepared by AEP method $\left(\mathrm{A}_{0}\right)$, the cells showed lower fluorescent intensity per cell when compared with those incubated with $\mathrm{R}_{0}$, prepared by the RREP method ( $74 \pm 10$ and $401 \pm 86$ fluorescent arbitrary unit/cell, respectively), although both presented low uptake when compared with fucoidan-coated nanoparticles. Indeed, the fluorescence intensity increased by 48- and 47-fold when comparing the uptake of $\mathrm{A}_{25}$ and $\mathrm{A}_{100}$, respectively with that of nanoparticles without fucoidan (i.e. $\mathrm{A}_{0}$ ) and 3-folds when $\mathrm{R}_{25}$ was compared with $\mathrm{R}_{0}$ nanoparticles. Additionally, for $\mathrm{A}_{25}$ and $\mathrm{A}_{100}$ nanoparticles, the fluorescence was mainly observed homogeneously distributed in the cytoplasm of the cells. However, a punctuate fluorescence was also observed in both calcein and merged images (Fig. 4A) suggesting that nanoparticles were sequestered within endosomal/lysosomal compartments $(36,37)$. Although the fluorescence intensity was lower, the 

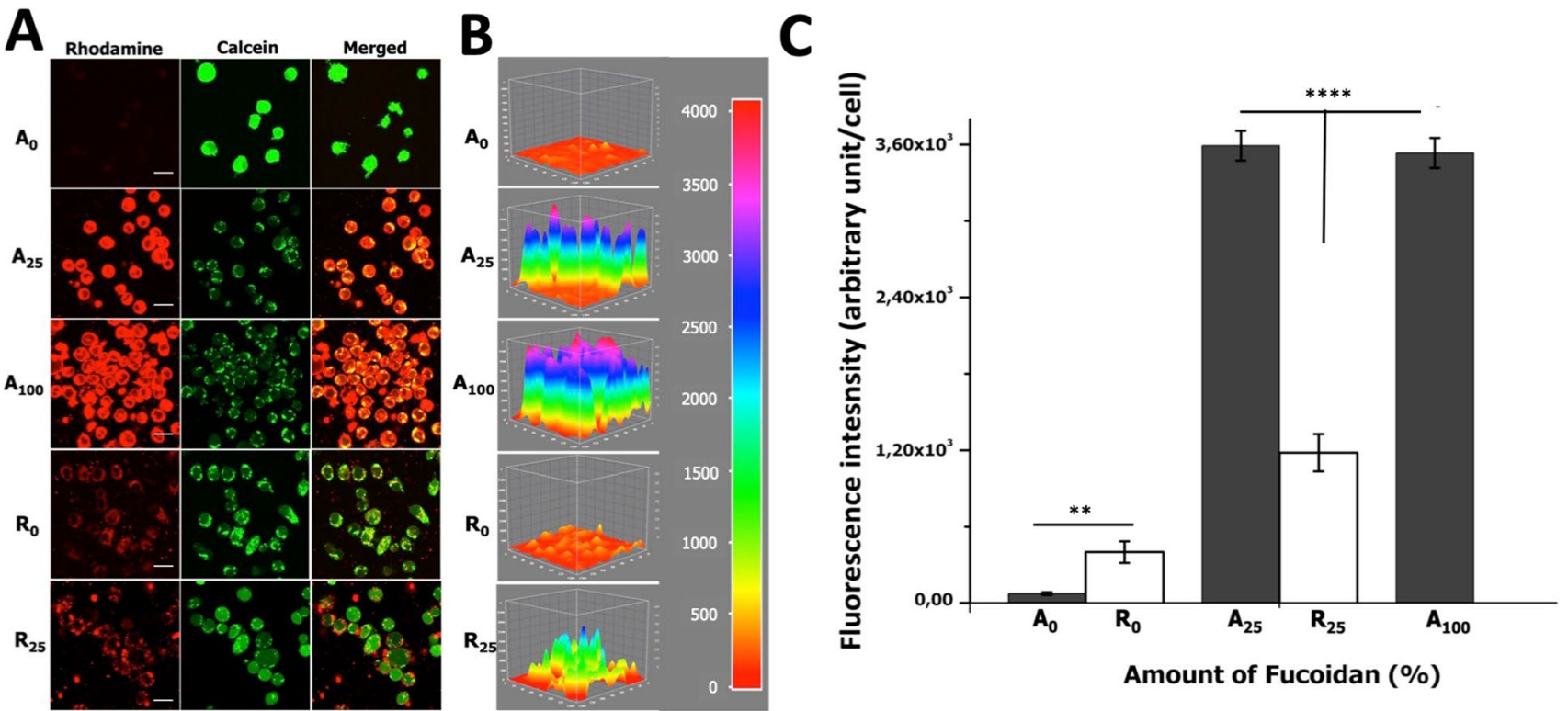

Scale Bars $=22 \mu \mathrm{m}$

Fig. 4 Uptake of nanoparticles by macrophages (J774A.1) after 1 hour of incubation $37^{\circ}$ C. (A) Confocal images of nanoparticle internalization. (B) 3D fluorescence intensity view obtained from the confocal images shown in (A), the scale bar of fluorescence intensity is from red to pink (0 - 4.000). (C) Data are indicated as fluorescence per cell, obtained after fluorescence quantification using confocal images. At least 100 individual cells from 10 different places were used for quantification and expressed as statistically different as $* *(p<0.05)$, and $* * * *(p<0.0001)$.

nanoparticles $\mathrm{R}_{0}$ and $\mathrm{R}_{25}$ also presented punctuated fluorescence inside the cells. Generally, no fluorescence was observed at the cell surface, except with the nanoparticles $\mathrm{R}_{25}$. The decrease in the fluorescence intensity of calcein observed while the fluorescence intensity of rhodamine increased was probably due to the fluorescence resonance energy transfer (FRET) phenomenon in which rhodamine and calcein can be considered as acceptor and donor, respectively (38).

The marked difference of intracellular uptake found between nanoparticles without fucoidan and those with fucoidan could be related to their zeta potential. As shown in Fig. 5, nanoparticles that are close to neutrality, $\mathrm{A}_{0}$ and $\mathrm{R}_{0}$, (zeta potential $-5.5 \pm 0.3$ and $-5.2 \pm 0.4 \mathrm{mV}$, respectively) seem to undergo lower cellular uptake than the negatively charged nanoparticles. The difference in the fluorescence intensity between these cells indicates that the nanoparticles $\mathrm{A}_{0}$ and $\mathrm{R}_{0}$ were not equivalent despite their similar size, surface composition and charge (Table I). The difference in the cellular uptake can be explained by the distinct molecular architecture of the polysaccharide chains at the surface of these two nanoparticle formulations as illustrated in Fig. 1 as determined in previous work (31).
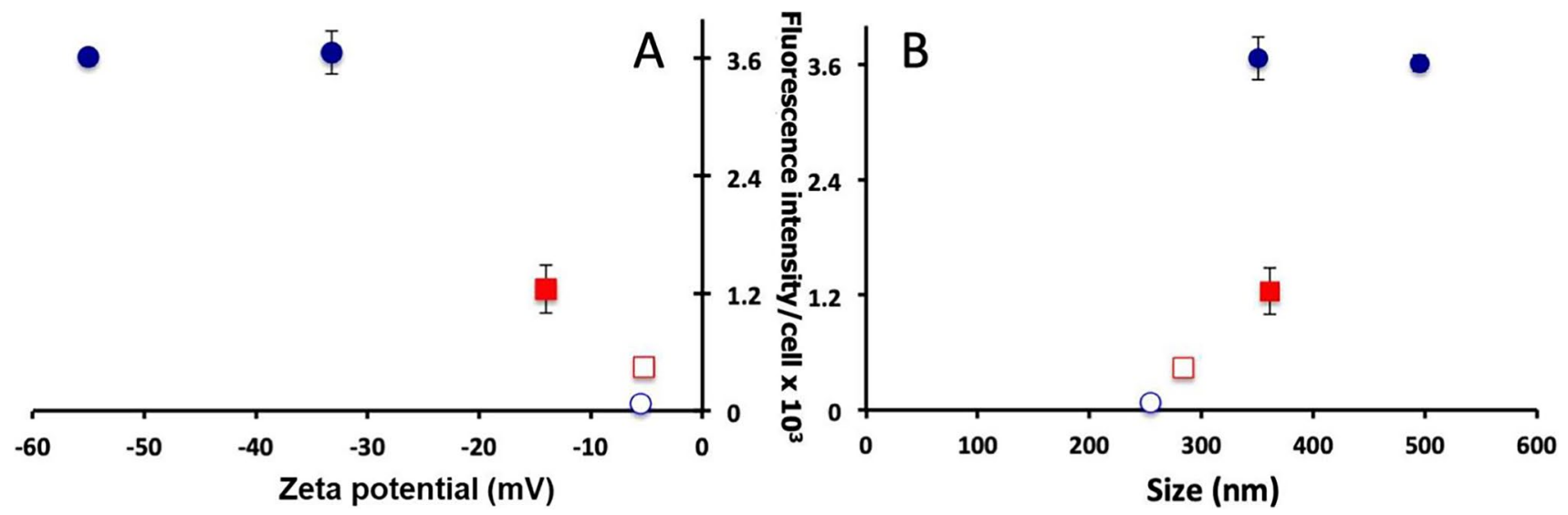

Fig. 5 Comparison between nanoparticle uptake as a function of zeta potential (A) and particle size (B). Squares represent $\mathrm{R}$ nanoparticles with fucoidan (red square) and without fucoidan (red open square). Circles represent A nanoparticles with fucoidan (blue full circles) and without fucoidan (blue open circle). 
It was also observed in Fig. 5A that cells incubated with the most negatively charged nanoparticles $\left(\mathrm{A}_{25}\right.$ and $\mathrm{A}_{100}$ zeta potential $-33.2 \pm 0.4 \mathrm{mV}$ and $-55 \pm 1 \mathrm{mV}$, respectively) presented the highest fluorescence intensity. Despite divergent studies concerning the influence of surface charge on nanoparticle internalization, the literature suggests that positively charged nanoparticles are the most internalized (19, 39). This is in contrast with our result, but the charge is not the only factor that influences nanoparticle internalization by cells; it may also be influenced by their composition (40). In this respect, the use of fucoidan as a coating molecule in these experiments, in addition to its arrangement on the surface of nanoparticles, markedly influenced the uptake by J774A.1 macrophages.

Observations of fluorescence differences between cells incubated with $\mathrm{A}_{25}$ and $\mathrm{R}_{25}$ provided further evidence that the molecular arrangement of the polysaccharide on the surface of nanoparticles influenced the internalization of the nanoparticles by the cells (Fig. 5). This was new additional evidence that the architectural disposition of polysaccharide on the surface of nanoparticles can promote different biological behavior, as suggested by other reports in the literature (20-22). The nanoparticles $\mathrm{A}_{25}$ were internalized 3-fold more than $\mathrm{R}_{25}$ (fluorescence intensity in arbitrary unit per cell 3,6 $\times 10^{3}$ and $1,2 \times 10^{3}$, respectively) although they were of similar size. Both nanoparticles contained $25 \%$ fucoidan in their corona but, because of the spatial configuration of the polysaccharide chains at the nanoparticle surface, the negative charges of fucoidan were largely exposed on $A_{25}$, while on the surface of $R_{25}$ nanoparticles they may be hidden (Fig. 1). The difference in the exposure of the negative charge of fucoidan at the surface of the nanoparticles could be one reason explaining the differences in intracellular uptake observed between these nanoparticles. Furthermore, it is noteworthy that fucoidan is a known substrate of the Scavengers Receptors (SR), especially type A (SR-A) found on macrophages. These types of receptors are present on the J774A.1 cell line $(29,41)$. These are primary endocytic receptors internalizing a number of substances including fucoidan as a sulfonated polysaccharide $(42,44)$. These receptors could be involved in the uptake of fucoidancoated nanoparticles by the J774A.1 macrophage cell line with a different uptake efficiency depending on the conformation of the fucoidan chains that could affect the accessibility of the fucoidan chain to the active site of the receptor. The relationship between the cell fluorescence and the volume of nanoparticles $\left(\mathrm{v}=1 / 6 \times \pi \times \mathrm{D}_{\mathrm{H}}{ }^{3}\right)$ was examined as detailed in Fig. 6. Differences were observed in the normalized uptake, again suggesting that each type of nanoparticles presented a distinct internalization mechanism. These results are consistent with the profile in Fig. 4C. The size influenced cell uptake as discussed previously (Fig. 5), and it can be noted that, once again, the results indicated that the

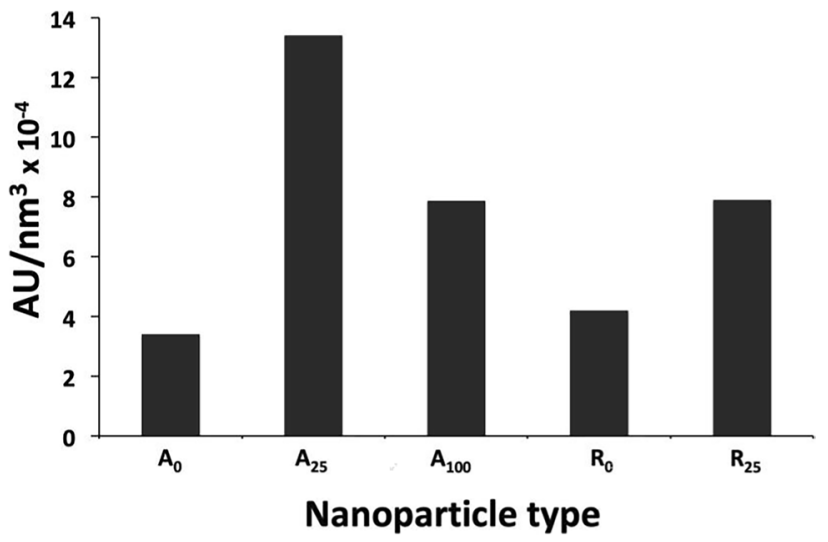

Fig. 6 Comparison of the fluorescence signal due to the nanoparticles captured by the cells normalized by the nanoparticle volume. The fluorescence of the cells determined in the Fig. 4 was divided by the volume of the corresponding nanoparticles calculated from their $\mathrm{D}_{\mathrm{H}}$ (Table I).

disposition of fucoidan on nanoparticle surface influenced cell internalization.

\section{Evaluation of the Energetic Dependency of the Internalization Mechanisms of PIBCA Nanoparticles by the Cells.}

Based on the results of the confocal microscopy presented above, the fluorescence of the cells measured by flow cytometry was interpreted as due to the cellular uptake of the nanoparticles. Variation of cell fluorescence measured by flow cytometry with the different nanoparticles shown on Fig. 7 (data at $37^{\circ} \mathrm{C}$ ) were consistent with those observed from image analysis of confocal micrographs (Fig. 4). The possibility of an energy- dependent internalization mechanism was evaluated by reducing the temperature of the incubation of the cells to $4{ }^{\circ} \mathrm{C}$, thereby cellular metabolism. As shown in Fig. 7A, the median fluorescence intensity of cells incubated with $\mathrm{A}_{0}$ and $\mathrm{R}_{0}$ at $4^{\circ} \mathrm{C}$ was considerably reduced compared with the fluorescence of cells incubated with the same nanoparticles at $37^{\circ} \mathrm{C}$. These reductions were 8 - and 4-fold for $\mathrm{A}_{0}$ and $\mathrm{R}_{0}$ nanoparticles respectively, giving evidence of the participation of energy-dependent endocytic mechanisms for their uptake by J774A.1 macrophages. In contrast, the association of nanoparticles $\mathrm{A}_{100}$ with J774A.1 macrophages did not appear to be different in cells incubated at the two temperatures, indicating that cells internalized these nanoparticles through energy- independent mechanisms. The results with nanoparticles $A_{25}$ and $R_{25}$ were intermediate. The fluorescence of the cells was reduced 0.5- and 1.5-fold respectively when the fluorescence of cells incubated at $4{ }^{\circ} \mathrm{C}$ was compared with those incubated at $37^{\circ} \mathrm{C}$, suggesting that both energy-dependent and independent mechanisms were involved in their internalization by J774A.1 macrophages. 

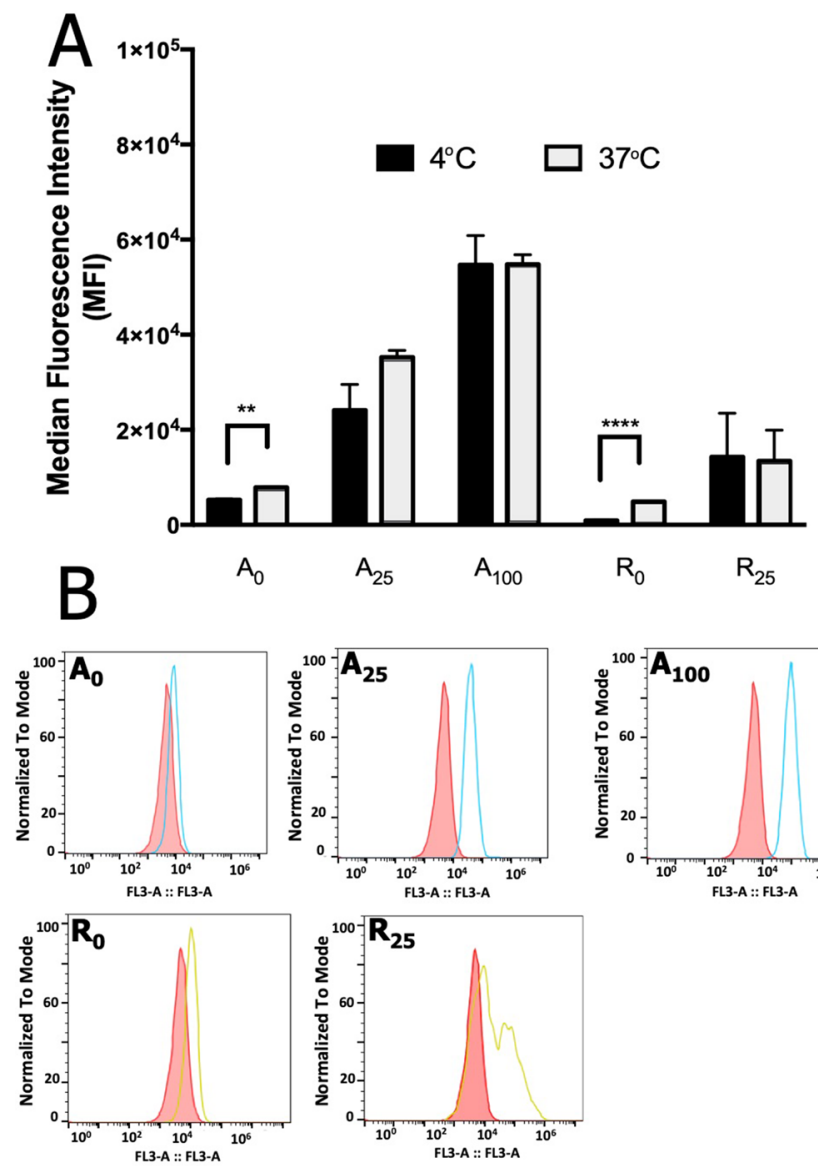
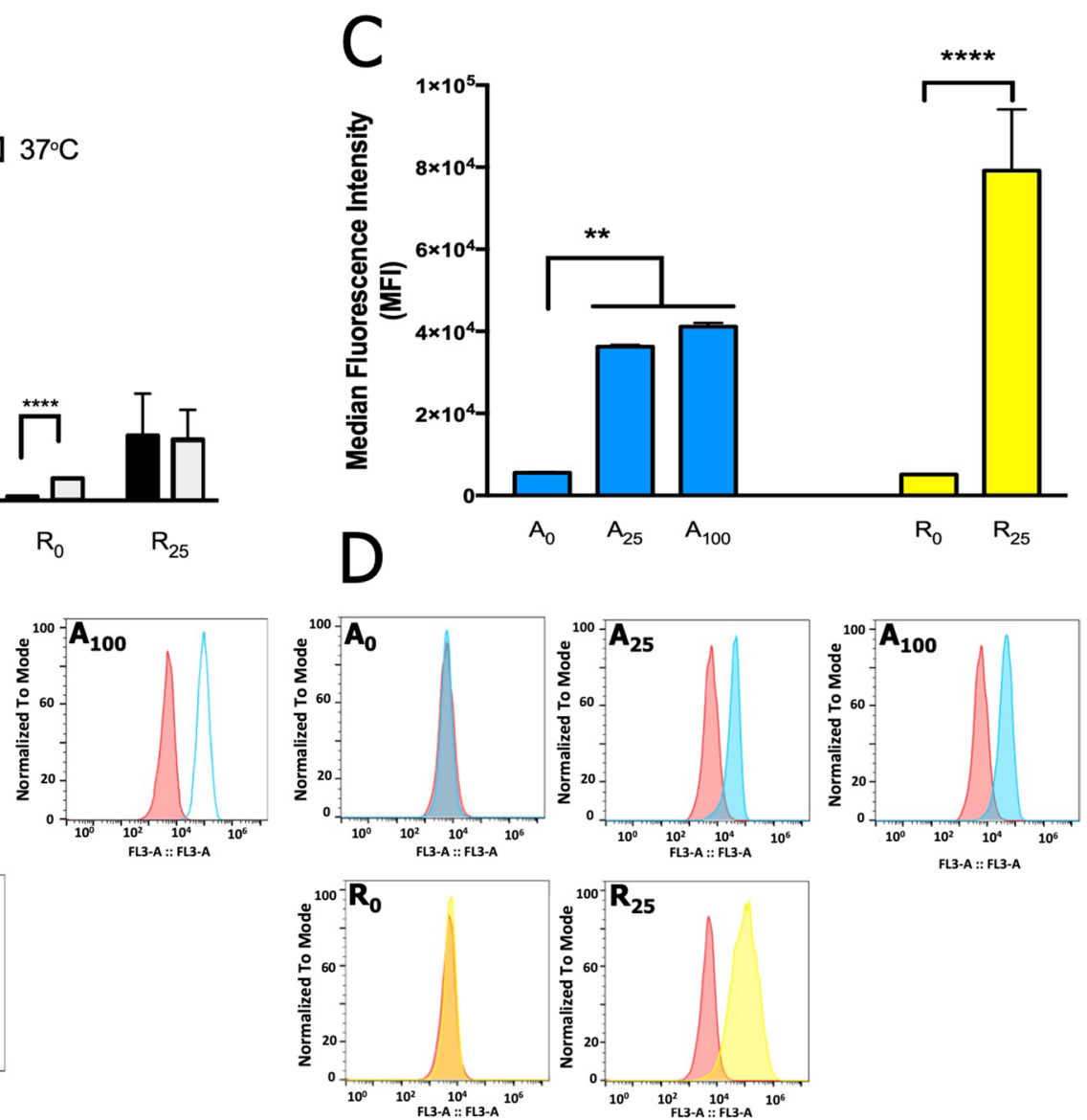

Fig. 7 Influence of incubation temperature on cell uptake of different PIBCA nanoparticles by macrophages (J774A.1) during (A and B) a long incubation or $(\mathbf{C}$ and $\mathbf{D})$ a short incubation $(10 \mathrm{~min})$. (A) The median fluorescent intensity (MFI) of the cells after 1 hour incubation with the nanoparticles at $37^{\circ} \mathrm{C}$ (black column) and $4{ }^{\circ} \mathrm{C}$ (light grey column). (B) Histograms of flow cytometry at $37^{\circ} \mathrm{C}$ : cells without nanoparticles (red); Cells with nanoparticles $\mathrm{A}_{0,} \mathrm{~A}_{25}$ and $\mathrm{A}_{100}$ (blue line); $\mathrm{R}_{0}$ and $\mathrm{R}_{100}$ (yellow line). Data were obtained by flow cytometry, in duplicate, analyzing 10.000 cells measured in each sample gate and expressed as statistically different as $* *(p<0.05)$ and $* * * *(p<0.0001)$. (C) Data expressed as median fluorescence intensity (\%) were obtained by flow cytometry, in duplicate, analyzing 10.000 cells measured in each sample gate. (D) Histograms of flow cytometry: cells without nanoparticles (red); Cells with $\mathrm{A}_{0}, \mathrm{~A}_{25}$ and $\mathrm{A}_{100}$ nanoparticles (blue); cells with $\mathrm{R}_{0}$ and $\mathrm{R}_{100}$ nanoparticles (yellow). Samples were analyzed in duplicate and expressed as statistically different as $* *(p<0.05)$ and $* * * *(p<0.0001)$.

Previously, Verma and Stellacci (34) described similar temperature-sensitive behavior for nanoparticles coated with a shell of hydrophobic and anionic ligands arranged in ribbon-like domains. The same authors reported that an organized, rather than random, arrangement of molecules on the surface of nanosystems provided unexpected surface properties (44). They observed that nanoparticles penetrated cell membranes both at $37{ }^{\circ} \mathrm{C}$ and $4{ }^{\circ} \mathrm{C}$ but at different levels, with higher internalization at $37^{\circ} \mathrm{C}$, and they suggested that the structural organization of nanoparticle surfaces influenced cell-membrane penetration (34). In this study, differences between nanoparticle types (A and $\mathrm{R}$ ) and also between nanoparticles of same type but with $\left(A_{25}\right.$ and $\left.R_{25}\right)$ and without fucoidan $\left(A_{0}\right.$ and $\left.R_{0}\right)$ were observed. Based on the energy dependency of the $\mathrm{R}_{0}$ and $\mathrm{A}_{0}$ internalization process by macrophages we can infer that an endocytic mechanism could be the dominant route of internalization of these nanoparticles. Concerning $\mathrm{R}_{25}$ and $\mathrm{A}_{25}$, which showed only a partial reduction of the fluorescence of the cells at $4{ }^{\circ} \mathrm{C}$, other mechanisms that are not dependent on energy were involved, as well as energy- dependent endocytic mechanisms. The fact that $\mathrm{A}_{100}$ entered cells by an energy-independent mechanism suggested that the uptake mechanism differed from the usually observed endocytosis pathways that are energy-dependent. The results were consistent with mechanisms which involve receptors, as was assumed earlier with respect to nanoparticles decorated with fucoidan.

\section{Influence of Reducing the Incubation Time on the Uptake of the PIBCA Nanoparticles by the Cells}

According to the literature, nanoparticles can be internalized by cells through different pathways that proceed at different rates (14). Watanabe and Boucrot (45) have focused their review paper on clathrin-independent endocytic process that are fast endocytic pathways in 
comparison with clathrin-mediated endocytosis processes which are considered too slow to internalize proteins from the cell surface during some physiological processes. To evaluate the rapidity at which the nanoparticles were internalized by cells, complementary experiments were performed using a shorter incubation time $(10 \mathrm{~min} v s 1$ hour at $37^{\circ} \mathrm{C}$ ) (Fig. 7C, D). Results from confocal microscopy (Fig. 2A) and flow cytometry (Fig. 7C, D) showed that all types of nanoparticles can be observed to have been taken up by J774A. 1 macrophages after $10 \mathrm{~min}$ of incubation (Fig. 2A, 7, C). For nanoparticles $\mathrm{A}_{0}, \mathrm{~A}_{25}$ and $\mathrm{R}_{0}$, the amount of fluorescence associated with the cells after 1 hour and after $10 \mathrm{~min}$ was quite similar (Fig. 2 and Fig. 7A, C). In contrast, the fluorescence increased between 10 min and 1 hour with $A_{100}$ nanoparticles and decreased dramatically for $\mathrm{R}_{25}$ nanoparticles. The differences noted between these groups of nanoparticles indicated marked differences in their rate of endocytosis. The dramatic reduction of fluorescence observed when cells were incubated with $R_{25}$ nanoparticles suggested an internalization by cells through a fast process. However, after having been internalized by the cells, the nanoparticles were rapidly eliminated from the cells. In contrast, the steady-state level of fluorescence shown by the cells incubated with $A_{0}, A_{25}$ and $R_{0}$ nanoparticles indicated that these nanoparticles were taken up by cells through a rapid mechanism and largely remained in the cells after having been captured. However, it cannot be excluded that the constant level of cell fluorescence observed between 10 min and 1 hour was the reflection of a state of equilibrium between efflux and capture mechanisms compensating each other. Only the fluorescence of the cells incubated with $\mathrm{A}_{100}$ nanoparticles increased between $10 \mathrm{~min}$ and 1 hour incubation indicating that their uptake by J774A.1 macrophages occurred by a slow process. The result observed with the nanoparticles $\mathrm{R}_{25}$ was intriguing, suggesting that the nanoparticles could be internalized well by the cells but followed an intracellular pathway which finally led to their elimination from the cells; that is, favoring nanoparticle efflux from the cells.

\section{Elucidation of the Endocytic Pathways Using Endocytic Pathway Inhibitors}

All the results reported above support our previous observation that the different types of nanoparticles were taken up by the J774A.1 macrophages by different routes. This last part of the work was designed to elucidate the different pathways by which nanoparticles penetrated cells in more detail. Different internalization pathways were investigated by incubating cells with pharmacological inhibitors known to block specific endocytic pathways. However, there are several limitations to this approach (14). For example, when a given endocytic pathway is blocked, another can be activated to compensate. Furthermore, some pharmacological inhibitors are not very specific, making it impossible to identify the endocytosis pathway precisely. Despite these challenges, this approach remains the most frequently used for this type of study.

The fluorescence associated with the cells incubated with the nanoparticles in the presence of inhibitors of endocytic pathways was monitored by both flow cytometry (Fig. 8) and confocal microscopy (Fig. 9), and compared with the signal obtained when cells were incubated in similar conditions without the inhibitors. It was assumed that the blockage of the preferred routes of entry of the nanoparticles would significantly reduce their accumulation in the cells hence the fluorescence of the cells. The uptake of each nanoparticle type was affected in a different fashion by the endocytic pathway inhibitors. The internalization of the nanoparticles $\mathrm{A}_{0}$, those prepared without fucoidan, was almost completely inhibited by chlorpromazine $(6.3 \pm 0.7 \%)$, genistein $(7.0 \pm$ $1.0 \%)$ and MeßCD (5.5 $\pm 0.4 \%)$ while cytochalasin D (34 $\pm 9 \%)$ and nocodazole $(56 \pm 2 \%)$ only partially inhibited
Fig. 8 Percentage (\%) of fluorescence of the cells grown in the presence of the pharmacological inhibitors of endocytic pathways compared to the fluorescence of cells grown in the absence of endocytic pathway inhibitors.

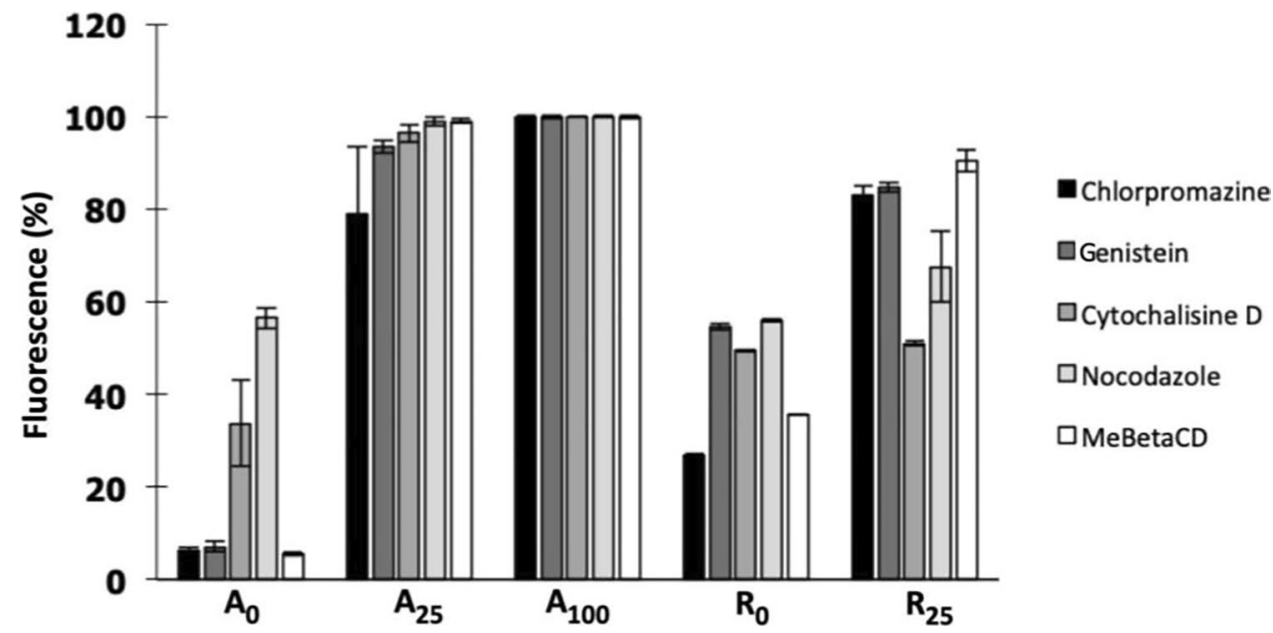



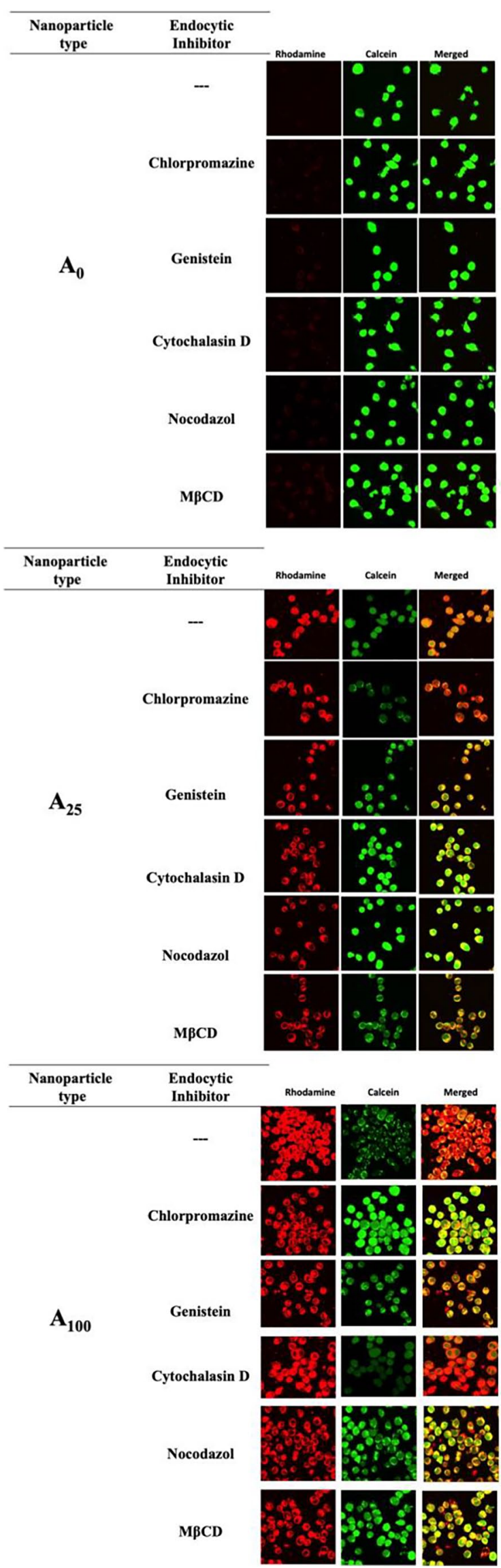
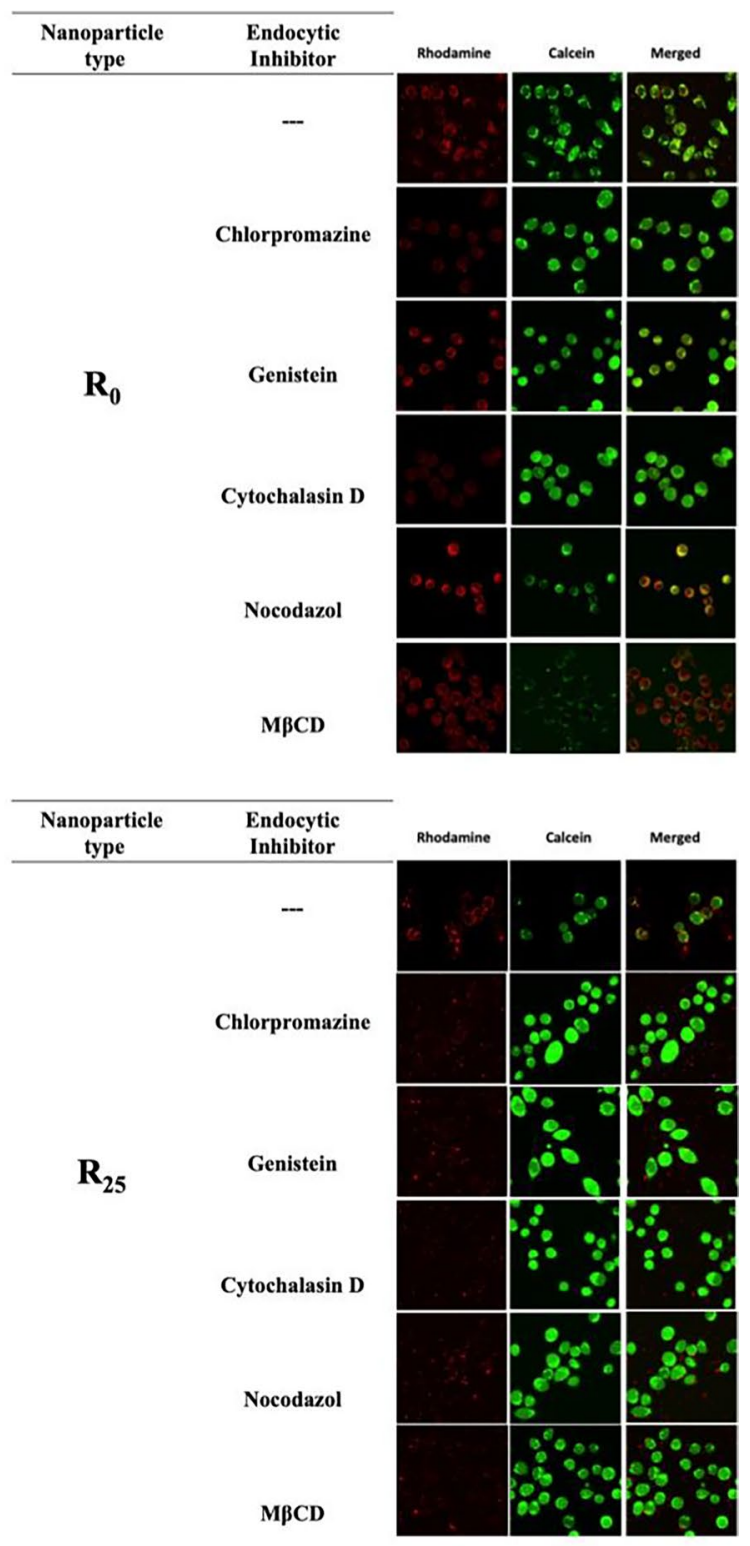
४Fig. 9 Evaluation of endocytic pathways using endocytic pathway inhibitors by confocal microscopy.

their uptake by the cells. Inhibition of the uptake of the nanoparticles $\mathrm{R}_{0}$ followed the same general pattern but with lower levels of inhibition. These results suggested that the preferred route of endocytosis of the $A_{0}$ nanoparticles was the clathrin-mediated pathway (CME). These nanoparticles could also penetrate cells by caveolin (CvME) and clathrincaveolae independent pathways but at a lower extent than by CME. This is consistent with previous observations that an endocytic pathway involving caveolae is taken by smallsized nanoparticles $(14,18)$. Clathrin and clathrin-caveolae independent pathways, in that order, were the preferred routes for the internalization of $\mathrm{R}_{0}$ nanoparticles. The endocytic pathways identified for $\mathrm{A}_{0}$ and $\mathrm{R}_{0}$ are energy-dependent, which is coherent with the conclusion of the experiments described above when cells were incubated with the nanoparticles at $4{ }^{\circ} \mathrm{C}$ (Fig. 7A and B).

In contrast, the uptake of fucoidan-coated nanoparticles $A_{25}$ and $R_{25}$ was less affected by the presence of endocytic pathway inhibitors and, in the case of $\mathrm{A}_{100}$ nanoparticles, not affected at all. The general lower effect of the inhibitors meant that the nanoparticles were able to bypass, at least in part, endocytic pathways, entering J774A.1 macrophages by other energy-independent mechanisms, in accordance with the results reported above (Fig. 7). The partial inhibition of the endocytic pathways recorded with $\mathrm{A}_{25}$ and $\mathrm{R}_{25}$ nanoparticles indicated that these nanoparticles were taken up by the J774A.1 macrophages by endocytic and non-endocytic pathways working concomitantly but at different extents. In contrast, since no endocytic pathway inhibitors prevented the uptake of the $\mathrm{A}_{100}$ nanoparticles, it can be assumed that they were taken up almost exclusively through non-endocytic pathways. Given that the particle diameter of $\mathrm{A}_{100}$ is around $500 \mathrm{~nm}$, phagocytic routes could be involved $(14,18)$, during which non-opsonic receptors interact with the surface of nanoparticles. These are known as pattern recognition receptor-mediated pathways (PRRs). According to the literature, these include scavenger receptors (SRs), Toll-like receptors (TLRs) and nucleotide-binding domain leucine-rich repeatcontaining receptors (NLRs) (46). PRRs are functional in the J774A. 1 cell line with some of these receptors recognizing carbohydrate patterns. For example, the macrophage scavenger receptors A (SR-A) can internalize polyanionic compounds like negatively charged carbohydrates such as fucoidan (47). Through this pathway, nanoparticles are expected to accumulate in the cytoplasm, in agreement with what was observed in the Fig. 4A (48). Other receptors, including the C-type lectin receptors (CLRs) and the mannose receptor (MR), can bind the fucose moieties of which fucoidan is composed. Binding to these receptors depends on both the negative charge of the molecule and the density of charge. It can be assumed that the nanoparticles containing fucoidan in their corona could be taken up by the J774A.1 macrophages as a result of interactions with such PRRs. However, the extent by which these nanoparticles were taken up by different entry routes also depended on other properties of the nanoparticles. All the endocytic pathways studied in this manuscript (CME, CvME, CCIP, etc) can direct nanoparticles to endosomes (49). This was evident from the punctuate fluorescence observed on the confocal fluorescence microscopy images shown in Figs. 3 and 4A.

For this series of nanoparticles, the balance of their uptake by endocytic and non-endocytic pathways clearly depended on the properties of the nanoparticles. An increase of the internalization of the nanoparticles through non endocytic routes was linked to (i) an increase in size of the nanoparticles, (ii) an increase of the absolute value of the negative zeta potential indicating an increase of the negative charge density at the surface of the nanoparticles, (iii) an increase in the fucoidan content in the composition of the nanoparticle outmost and (iv) the exposure of fucoidan in the configuration in loops and trains at the nanoparticle surface. As shown in Fig. 10, a clear hierarchy defining the predominant mechanism by which nanoparticles were taken up by cells could be established, going from one extreme to the other of each of these parameters.

It should be noted that, from a quantitative point of view, the types of nanoparticles taken up by endocytic mechanisms appeared, by far, to be the least internalized by the J774A. 1 cells. In contrast, those penetrating cells by a nonendocytic pathway, phagocytic routes assumed to involve a pattern recognition receptor recognizing fucoidan, were taken up by the cells to a much higher extent. This superior uptake ability would be advantageous for intracellular delivery of drugs. This is in accordance with the paper of Mosaia and co-workers (50) suggesting that nanoparticles exposing glycans on their surface could be suitable carriers to deliver drug inside macrophages thanks to their interaction with specific PRRs.

\section{CONCLUSION}

The present work has shown that the internalization pathways taken by polysaccharide-coated PIBCA nanoparticles to penetrate J774A.1 macrophages can be determined by the surface composition in fucoidan and dextran and from the configuration given to the polysaccharide chains. The privileged routes of internalization of the PIBCA nanoparticles by the cells included non-endocytic pathways which appeared 3.3-fold more efficient than endocytic pathways when the extend of internalization of $A_{100}$ nanoparticles (coated with $100 \%$ fucoidan) and $\mathrm{A}_{0}$ nanoparticles (coated with dextran only) were compared. Non-endocytic 


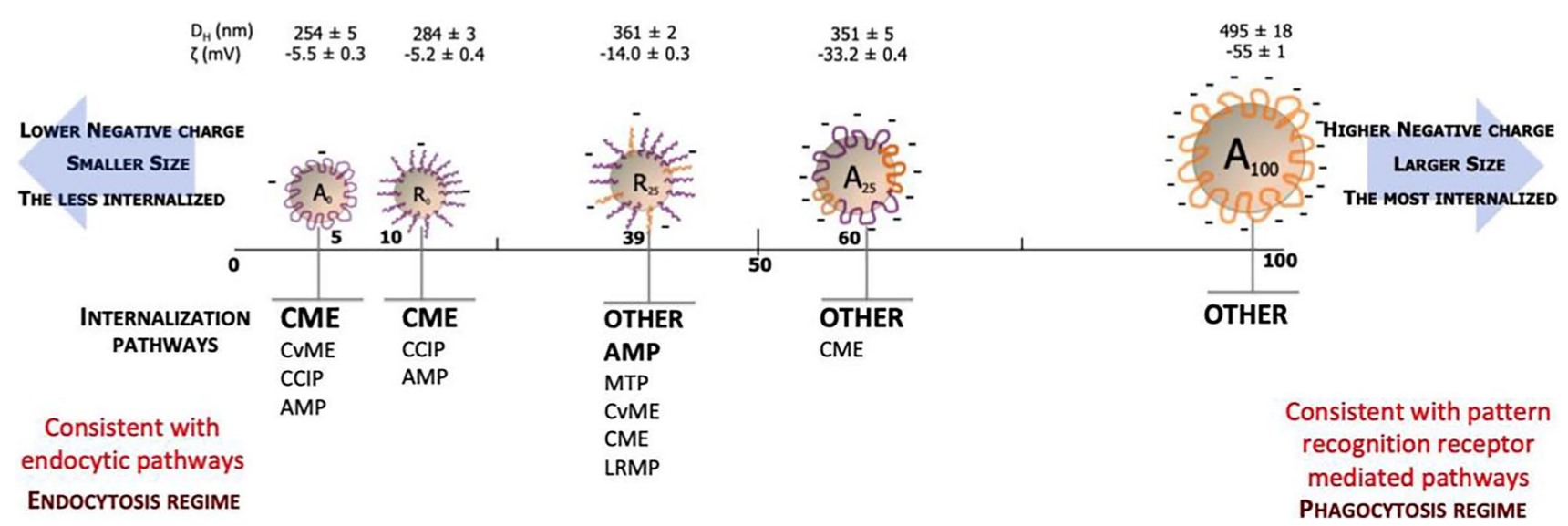

Fig. 10 Summary figure indicating the predominant mechanism by which nanoparticles were taken up by cells. In bold, the predominant pathway. Abbreviations: CME: Clathrin-mediated endocytosis, CvME: Caveolae-mediated endocytosis, CCIP: Clathrin-caveolae independant pathways, AMP: Actin-mediated pathway that can apply to macropinocytosis and phagocytosis, MTP: Microtubule-mediated pathways, LRMP: Lipid raft-mediated pathways, other: none of the above-mentioned pathways. The number of negative charges in the cloud represents the relative values shown by the zeta potential of the nanoparticles. The size shown by the nanoparticles represents their relative size.

pathways providing high intracellular uptake were favored by a large size of the fucoidan-coated PIBCA nanoparticles $(495 \pm 18 \mathrm{~nm})$, a high density of negative charge on the nanoparticle surface (zeta potential $-55 \pm 1 \mathrm{mV}$ ) and by the presence of fucoidan exposed in the loop and train conformation at the nanoparticle surface. In contrast, endocytosis through energy-dependent routes (endocytic pathways) were favored by a smaller size of the nanoparticles $(254 \pm 5 \mathrm{~nm})$ and a composition of their corona made of dextran only. The general increased uptake of fucoidancoated nanoparticles $\left(\mathrm{A}_{25}, \mathrm{~A}_{100}\right.$ and $\left.\mathrm{R}_{25}\right)$ by J774A.1 macrophages was attributed to a privileged interaction of the nanoparticles with carbohydrate recognition receptors, as part of macrophage scavenger receptors, but this deserves to be elucidated further. The difference in the intracellular distribution observed between nanoparticles of type $\mathrm{A}$ $\left(\mathrm{A}_{25}, \mathrm{~A}_{100}\right)$, accumulating in the cell cytoplasm, and nanoparticles of type $R\left(R_{0}, R_{25}\right)$ accumulating in intracellular compartments also deserves attention. Pursuing this work by deciphering the intracellular trafficking arising from the different routes by which nanoparticles were taken up by J774A.1 macrophages could improve the design efficacy of nanoparticles able to achieve efficient cytoplasmic drug delivery.

Supplementary Information The online version contains supplementary material available at https://doi.org/10.1007/s11095-022-03202-4.

ACKNOWLEDGEMENTS AND DISCLOSURES The authors would like to thank Dr Gillian Barratt for her careful reading of our manuscript and help in improving the English language. The authors gratefully acknowledge the support by Conselho Nacional de Pesquisa Científica CNPq (\#249904/2013-06), CNPq Universal (\#427243/2016-5) Auxílio Pesquisador 065880/2020-93 and Qualis A (23076.054228/2020-29). CAPES-COFECUB project 721/11. CAPES Print (\#2761/2018). They also thank the Région Ile-de-France and the Université Paris-Saclay for financial support to MIPSIT core facility confocal microscopy was performed. Not applicable. The authors declare no conflicts of interest.

\section{References}

1. Kou L, Sun J, Zhai Y, He Z. The endocytosis and intracellular fate of nanomedicines: Implication for rational design. Asian J Pharm Sci. 2013;8:1-10. https://doi.org/10.1016/j.ajps.2013.07.001.

2. Song H, Yu M, Lu Y, Gu Z, Yang Y, Zhang M, Fu J, Yu C. Plasmid DNA Delivery: Nanotopography Matters. J Am Chem Soc. 2017;139:18247-54. https://doi.org/10.1021/jacs.7b08974.

3. Watson P, Jones AT, Stephens DJ. Intracellular trafficking pathways and drug delivery: fluorescence imaging of living and fixed cells. Adv Drug Deliv Rev. 2005;57:43-61. https://doi.org/10. 1016/j.addr.2004.05.003.

4. Wu Z, Li T. Nanoparticle-Mediated Cytoplasmic Delivery of Messenger RNA Vaccines: Challenges and Future Perspectives. Pharm Res. 2021;38:473-8. https://doi.org/10.1007/ s11095-021-03015-x.

5. Zhao J, Stenzel MH. Entry of nanoparticles into cells: the importance of nanoparticle properties. Polym Chem. 2018;9:259-72. https://doi.org/10.1039/C7PY01603D.

6. Chavany C, Le Douan T, Couvreur P, Puisieux F, Hélène C. Polyalkylcyanoacrylate nanoparticles as polymeric carriers for antisense oligonucleotides. Pharm Res. 1992;9:441-9. https://doi.org/ 10.1023/A:1015871809313.

7. Cavalcanti IDL, Ximenes RM, Pessoa ODL, Santos-Magalhães NS, Lira-Nogueira MCB. Fucoidan-coated PIBCA nanoparticles containing oncocalyxone A: Activity against metastatic breast cancer cells. J Drug Del Sci Tech. 2021;65:102698. https://doi. org/10.1016/j.jddst.2021.102698.

8. Couvreur P, Kante B, Roland M, Guiot P, Bauduin P, Speiser P. Polycyanoacrylate nanocapsules as potential lysosomotropic carriers: preparation, morphological and sorptive properties. J Pharm Pharmacol. 1979;31:331-2. https://doi.org/10.1111/j.2042-7158. 1979.tb13510.x.

9. Lambert G, Fattal E, Pinto-Alphandary H, Gulik A, Couvreur P. Polyisobutylcyanoacrylate nanocapsules containing an aqueous core as a novel colloidal carrier for the delivery of 
oligonucleotides. Pharm Res. 2000;17:707-14. https://doi.org/10. 1023/a:1007582332491.

10. de Martimprey H, Vauthier C, Malvy C, Couvreur P. Polymer nanocarriers for the delivery of small fragments of nucleic acids: oligonucleotides and siRNA. Eur J Pharm Biopharm. 2009;71:490-504. https://doi.org/10.1016/j.ejpb.2008.09.024.

11. Merle P, Camus P, Abergel A, Pageaux GP, Masliah C, Bronowicki JP, et al. Safety and efficacy of intra-arterial hepatic chemotherapy with doxorubicin-loaded nanoparticles in hepatocellular carcinoma. ESMO Open. 2017;2:e000238. https://doi.org/10. 1136/esmoopen-2017-000238.

12. Schwab G, Chavany C, Duroux I, Goubin G, Lebeau J, Hélène C, Saison-Behmoaras T. Antisense oligonucleotides adsorbed to polyalkylcyanoacrylate nanoparticles specifically inhibit mutated Ha-ras-mediated cell proliferation and tumorigenicity in nude mice. Proc Natl Acad Sci U S A. 1994;91:10460-4. https://doi. org/10.1073/pnas.91.22.10460.

13. Soma E, Attali P, Merle P. A clinically relevant case study: the development of Livatag ${ }^{\circledR}$ for the treatment of advanced hepatocellular carcinoma. In: Alonso MJ, Csaba NS, editors. RSC Drug Discovery Series $N^{\circ} 22$ : Nanostructured Biomaterials for Overcoming Biological Barriers. Dorchester (UK): The Royal Society of Chemistry; 2012. p. 591-600.

14. Rennick JJ, Johnston APR, Parton RG. Key principles and methods for studying the endocytosis of biological and nanoparticle therapeutics. Nat Nanotechnol. 2021;16:266-76. https://doi.org/ 10.1038/s41565-021-00858-8.

15. Andrade RGD, Reis B, Costas B, Lima SAC, Reis S. Modulation of Macrophages M1/M2 Polarization Using CarbohydrateFunctionalized Polymeric Nanoparticles. Polymers. 2021;13:88. https://doi.org/10.3390/polym13010088.

16. Forest V, Pourchez J. Preferential binding of positive nanoparticles on cell membranes is due to electrostatic interactions: A too simplistic explanation that does not take into account the nanoparticle protein corona. Mater Sci Eng C. 2017;70:889-96. https://doi.org/ 10.1016/j.msec.2016.09.016.

17. Ghofrani M, Shirmard LR, Dehghankelishdi P, Amini M, Dorkoosh FA. Development of Octreotide-loaded chitosan and heparin nanoparticles: evaluation of surface modification effect on physicochemical properties and macrophage uptake. J Pharm Sci. 2019;108:3036-45. https://doi.org/10.1016/j.xphs.2019.05. 002 .

18. Iversen TG, Skotland T, Sandvig K. Endocytosis and intracellular transport of nanoparticles: Present knowledge and need for future studies. Nano Today. 2011;6:176-85. https://doi.org/10.1016/j. nantod.2011.02.003.

19. Souza de Almeida M, Susnick E, Drasler B, Taladriz-Blanco P, Petri-Fink A, Rothen-Rutishauser B. Understanding nanoparticles endocytosis to improve targeting strategies in nanomedicine. Chem Soc Rev. 2021,50, 5397-5434. doi: https://doi.org/10.1039/ D0CS01127D.

20. Alhareth K, Vauthier C, Bourasset F, Gueutin C, Ponchel G, Moussa F. Conformation of surface-decorating dextran chains affects the pharmacokinetics and biodistribution of doxorubicinloaded nanoparticles. Eur J Pharm Biopharm. 2012;81:453-7. https://doi.org/10.1016/j.ejpb.2012.03.009.

21. Coty JB, Oliveira EE, Vauthier C. Tuning complement activation and pathway through controlled molecular architecture of dextran chains in nanoparticle corona. Int J Pharm. 2017;532:769-78. https://doi.org/10.1016/j.ijpharm.2017.04.048.

22. Hamad I, Al-Hanbali O, Hunter AC, Rutt KJ, Andresen TL, Moghimi SM. Distinct polymer architecture mediates switching of complement activation pathways at the nanosphere - serum interface: implications for stealth nanoparticles engineering. ASC Nano. 2010;4:6629-38. https://doi.org/10.1021/nn101990a.
23. Peracchia MT, Vauthier C, Passirani C, Couvreur P, Labarre D. Complement consumption by poly(ethylene glycol) in different conformations chemically coupled to poly(isobutyl 2-cyanoacrylate) nanoparticles. Life Sci. 1997;61:749-61. https://doi.org/10. 1016/s0024-3205(97)00539-0.

24. Muro S. Alterations in Cellular Processes Involving Vesicular Trafficking and Implications in Drug Delivery. Biomimetics (Basel). 2018;3:19. https://doi.org/10.3390/biomimetics3030019.

25. Oh N, Park JH. Endocytosis and exocytosis of nanoparticles in mammalian cells. Int J Nanomedicine. 2014;9(Suppl 1):51-63. https://doi.org/10.2147/IJN.S26592.

26. Sahay G, Alakhova DY, Kabanov AV. Endocytosis of nanomedicines. J Control Release. 2010;145:182-95. https://doi.org/10. 1016/j.jconrel.2010.01.036.

27. Zhao J, Hu B, Xiao H, Yang Q, Cao Q, Li X, et al. Fucoidan reduces lipid accumulation by promoting foam cell autophagy via TFEB. Carbohydr Polym. 2021;268:118247. https://doi.org/ 10.1016/j.carbpol.2021.118247.

28. Lira MC, Santos-Magalhães NS, Nicolas V, Marsaud V, Silva MP, Ponchel G, Vauthier C. Cytotoxicity and cellular uptake of newly synthesized fucoidan-coated nanoparticles. Eur J Pharm Biopharm. 2011;79:162-70. https://doi.org/10.1016/j.ejpb.2011. 02.013.

29. Wang H, Wu L, Reinhard BM. Scavenger receptor mediated endocytosis of silver nanoparticles into J774A.1 macrophages is heterogeneous. ACS Nano. 2012;6:7122-32. https://doi.org/10. 1021/nn302186n.

30. Vauthier C, Schmidt C, Couvreur P. Measurement of the Density of Polymeric Nanoparticulate Drug Carriers by Isopycnic Centrifugation. J Nanoparticle Res. 1998;1:411-8. https://doi.org/10. 1023/A:1010031605547.

31. Bertholon I, Vauthier LD. Characterization of Dextranpoly(isobutylcyanocrilate) copolymers obtained by redox radical and anionic emulsion polymerization. Macromolecules. 2006a;39:3559-67. https://doi.org/10.1021/ma060338z.

32. Bertholon I, Vauthier C, Labarre D. Complement activation by core-shell poly(isobutylcyanocrylate) nanoparticles: influences if surface morphology, length and type of polysaccharide. Pharm Res. 2006b;23:1313-23. https://doi.org/10.1007/ s11095-006-0069-0.

33. Zandanel C, Vauthier C. Poly(isobutylcyanoacrylate) nanoparticles decorated with chitosan: effect of conformation of chitosan chains at the surface on complement activation properties. J Colloid Sci Biotechnol. 2012;1:68-81. https://doi.org/10.1166/jcsb. 2012.1004.

34. Verma A, Stellacci F. Effect of surface properties on nanoparticlecell interactions. Small. 2010;6:12-21. https://doi.org/10.1002/ smll.200901158.

35. Wang W, Gaus K, Tilley RD, Gooding JJ. The impact of nanoparticle shape on cellular internalisation and transport: what do the different analysis methods tell us? Mater. Horiz. 2019;6:1538-47. https://doi.org/10.1039/C9MH00664H.

36. Teo SLY, Rennick JJ, Yuen D, Al-Wassiti H, Johnston APR, Pouton CW. Unravelling cytosolic delivery of cell penetrating peptides with a quantitative endosomal escape assay. Nat Commun. 2021;12:3721. https://doi.org/10.1038/s41467-021-23997-x.

37. Wong ASM, Mann SK, Czuba E, Sahut A, Liu H, Suekama TC, et al. Self-assembling dual component nanoparticles with endosomal escape capability. Soft Matter. 2015;11:2993-3002. https:// doi.org/10.1039/C5SM00082C.

38. Thompson RB. Fluorescence Sensors and Biosensors. 1st ed. Boca Raton: CRC Press; 2005. https://doi.org/10.1201/9781420028287.

39. Foroozandeh P, Aziz AA. Insight into cellular uptake and intracellular trafficking of nanoparticles. Nanoscale Res Lett. 2018;13:339. https://doi.org/10.1186/s11671-018-2728-6. 
40. Jeon S, Clavadetscher J, Lee DK, Chankeshwara SV, Bradley M, Cho WS. Surface Charge-Dependent Cellular Uptake of Polystyrene Nanoparticles. Nanomaterials. 2018;8:1028. https://doi.org/ 10.3390/nano8121028.

41. Yu H, Ha T, Liu L, Wang X, Gao M, Kelley J, et al. Scavenger receptor A (SR-A) is required for LPS-induced TLR4 mediated NF- $\kappa$ B activation in macrophages. Biochim Biophys Acta. 2012;1823:1192-8. https://doi.org/10.1016/j.bbamcr.2012.05.004.

42. Hamasaki S, Kobori T, Yamazaki Y, Kitaura A, Niwa A, Nishinaka T, et al. Effects of scavenger receptors-1 class A stimulation on macrophage morphology and highly modified advanced glycation end product-protein phagocytosis. Sci Rep. 2018;8:5901. https://doi.org/10.1038/s41598-018-24325-y.

43. Lin Z, Tan X, Zhang Y, Li F, Luo P, Liu H. Molecular Targets and Related Biologic Activities of Fucoidan: A Review. Mar Drugs. 2020;18:376. https://doi.org/10.3390/md18080376.

44. Verma A, Uzun O, Hu Y, Hu Y, Han HS, Watson N, Chen S, Irvine DJ, Stellacci F. Surface-structure-regulated cell-membrane penetration by monolayer-protected nanoparticles. Nat Mater. 2008;7:588-595. https://doi.org/10.1038/nmat2202. Erratum in: Nat Mater. 2013;12:376.

45. Watanabe $\mathrm{S}$, Boucrot E. Fast and ultrafast endocytosis. Curr Opin Cell Biol. 2017;47:64-71. https://doi.org/10.1016/j.ceb.2017.02. 013.
46. Hirota K, Kerada H. Endocytosis of Particle Formulations by Macrophages and Its Application to Clinical Treatment. In: Caresa B. Editor. Molecular Regulation of Endocytosis. [Internet]. London: IntechOpen. 2012. https://doi.org/10.5772/45820.

47. Verbij FC, Sorvillo N, Kaijen PHP, Hrdinova J, Peyron I, Fijnheer $\mathrm{R}$ et al. The class I scavenger receptor CD163 promotes internalization of ADAMTS13 by macrophages. Blood Adv. 2017;1:293305. https://doi.org/10.1182/bloodadvances.2016001321. Erratum in: Blood Adv. 2020;4(3):499.

48. Shannahan JH, Bai W, Brown JM. Implications of scavenger receptors in the safe development of nanotherapeutics. Receptors Clin Investig. 2015;2:e811. https://doi.org/10.14800/rci.811.

49. Manzanares D, Ceña V. Endocytosis: The Nanoparticle and Submicron Nanocompounds Gateway into the Cell. Pharmaceutics. 2020;12:371. https://doi.org/10.3390/pharmaceutics12040371.

50. Mosaia T, Farr D, Kiefel MJ, Houston TA. Carbohydrate-based nanocarriers and their application to target macrophages and deliver antimicrobial agents. Adv Drug Deliv Rev. 2019;151152:94-129. https://doi.org/10.1016/j.addr.2019.09.002.

Publisher's Note Springer Nature remains neutral with regard to jurisdictional claims in published maps and institutional affiliations. 